\title{
High - sensitivity Troponin T-clinical progress or just more noise?
}

\author{
Scott Shurmur MD
}

The $5^{\text {th }}$ generation Troponin T assay, commonly referred to as "high sensitivity Troponin" or hs-cTnT, has been validated and used for several years in many countries, primarily in Europe and Australia, but was only recently approved by the FDA for use in the United States. It differs from "standard" or " 4 th generation" troponin assays in several important ways.

The sample size is increased from 15 to 50 microliters, increasing the chances of "recovery." Other modifications include signal amplification and genetic re-engineering of the chimeric antibody itself to improve precision and performance. Importantly, however, the assay detects the identical Troponin T epitopes as previous generations. As with other "high sensitivity assays" (such as hs-CRP), results are now reported in whole numbers per liter. For instance, a previous Troponin T value of $0.019 \mathrm{ng} / \mathrm{ml}$ would be reported at $19 \mathrm{ng} / \mathrm{l}$. The new assay has a very low "limit of blank" - the level at which Troponin T can reliably be detected - and the limit of quantification is $6 \mathrm{ng} / \mathrm{l}$.

New protocols for "rule out" of chest pain patients presenting to emergency departments (ED) have been developed. With such low levels of hs-cTnT detectable, patients can be ruled out (or in) for myocardial infarction (MI) much earlier, within one hour of presentation if chest pain has been present for at least three hours. A second hs-cTnT level is also drawn, generally at three hours post presentation. The "cut points" for positivity of this assay is based upon the $99^{\text {th }}$ percentile of hs-cTnT in healthy individuals, which is $14 \mathrm{ng} / \mathrm{l}$ for women and $22 \mathrm{ng} / \mathrm{l}$ in men.

\author{
Corresponding author: Scott Shurmur \\ Contact Information: Scott.shurmur@ttuhsc.edu \\ DOI: $10.12746 /$ swrccc.v6i25.474
}

Often, a "compromise" level of $19 \mathrm{ng} / \mathrm{l}$ has been used for both genders.

In the APACE study, a 1 hour "rule-in" level of $14 \mathrm{ng} / \mathrm{l}$ was initially applied. A second analysis was performed using FDA approved levels: $6 \mathrm{ng} / \mathrm{l}$ for rule out and $19 \mathrm{ng} / \mathrm{l}$ for rule in. In the 3267 patients, MI was the final diagnosis in $15.8 \%$ of patients using 14 $\mathrm{ng} / \mathrm{l}$, and $15.5 \%$ using $19 \mathrm{ng} / \mathrm{l}$. The negative predictive values and sensitivity of $\mathrm{Ml}$ diagnosis were greater than $99 \%$ whether 5 or $6 \mathrm{ng} / \mathrm{l}$ was used as the rule out value. The positive predictive value and specificity of hs-cTnT for Ml diagnosis were not as high, however, generally ranging from $50 \%$ to $75 \% .^{1}$ Interestingly, in the sites participating in the APACE study, switching to the use of hs-cTnT increased the frequency of $\mathrm{Ml}$ diagnosis (10\% vs $14 \%$ ), reduced the use of stress testing in ED chest patients (29\% to $19 \%)$, and reduced the median time to discharge from the ED (by $>9$ minutes). Mean total costs in these patients decreased by $20 \%$, despite no change in the use of invasive coronary angiography (23\% both before and after use of the new assay). ${ }^{2}$

In summary, use of the "generation 5", or high-sensitivity Troponin T presents a new, more efficient way to rule in or out the presence of myocardial necrosis in patients presenting with chest pain. If properly applied, costs and ED discharge times may decrease as well.

Keywords: troponin $\mathrm{T}$ assay, sensitivity, myocardial infarction

From: Department of Internal Medicine, Texas Tech University Health Sciences Center, Lubbock, TX

Submitted: 5/7/2018

Conflicts of interest: none

This work is licensed under a Creative Commons Attribution-ShareAlike 4.0 International License. 


\section{REFERENCES}

1. Charpentier S, Peschanski N, Chouihed T, et al. Multicenter evaluation of a 0-hour/1-hour algorithm in the diagnosis of myocardial infarction with high-sensitivity cardiac troponin T. Ann Emerg Med 2016 Jun;67(6):793-794.
2. Twerenbold R, Jaeger C, Rubini Giminez M, et al. Impact of high-sensitivity cardiac troponin on use of coronary angiography, cardiac stress testing, and time to discharge in suspected acute myocardial infarction. Eur Heart J 2016 Nov 21;37(44):3324-3332. 